\begin{tabular}{l|c|c}
\hline ISSN: 0001-5113 & ACTA ADRIAT., & ORIGINAL SCIENTIFIC PAPER \\
AADRAY & $60(1): 79-88,2020$ & \\
\hline
\end{tabular}

\title{
Growth characteristics of the European hake, Merluccius merluccius (Linnaeus, 1758), inhabiting northeastern Mediterranean
}

\author{
Hulya GIRGIN ${ }^{1,2}$ and Nuri BAȘUSTA ${ }^{2 *}$ \\ ${ }^{1}$ Faculty of Veterinary, Dokuz Eylül University, 35890, Kiraz, Izmir, Turkey \\ ${ }^{2 *}$ Faculty of Fisheries, Firat University, 23119, Elazig, Turkey \\ *Corresponding author,e-mail: nbasusta@firat.edu.tr
}

\begin{abstract}
In this study, the age and some growth characteristics of the European hake, Merluccius merluccius, from the northeastern Mediterranean were examined during 2015-2016 fishing season. A total of 661 European hake ranging from 9.8 to $51.6 \mathrm{~cm}$ in total length was captured by commercial trawler. Female/male ratio was 1/1.15. Age determination was conducted using the sagittal otoliths. Ages of examined individuals ranged from 1 to 7 years. The von Bertalanffy growth parameters fitted to the average measured total lengths-at-age for each sex separately and estimated as $L_{\infty}=93.98$ $\mathrm{cm}, k=0.114$ year $^{-1}, t_{0}=-0.597$ year for females, as $L_{\infty}=77.65 \mathrm{~cm}, k=0.153$ year $^{-1}, t_{0}=-0.343$ year for males and as $L_{\infty}=84.44 \mathrm{~cm}, k=0.135$ year $^{-1}, t_{0}=-0.469$ year for combined sexes. The growth performance value $(\Phi)$ of the European hake population was computed as 2.98 for combined sexes. Mean condition factor value for population was $0.654 \pm 0.021$; the highest condition factor was found as 1.01 in fish at age 7.
\end{abstract}

Key words: European hake, Merluccius merluccius, age, growth, northeastern Mediterranean, condition factor

\section{INTRODUCTION}

The European hake Merluccius merluccius (Linnaeus, 1758) is a demersal and bathypelagic fish inhabiting muddy substrates, from 100 to $1000 \mathrm{~m}$ (GOLANI et al., 2006). It is known as Atlanto-Mediterranean and is distributed from Norway and Iceland to Mauritania. European hake is an important commercial species in the European Union and Turkey (SOYKAN et al., 2015). European Hake is declining due to fishing pressure from commercial fisheries in the eastern Mediterranean and declines were greater than $30 \%$ over the past $20-40$ years based on reported FAO landings (FAO, 2017). According to SOYKAN et al., (2015) European hake is among the most heavily exploited fish species in the western European demersal fisheries and in Turkish Seas. Landings of M. merluccius in Turkish seas have declined from 20.810 tons in 2001 to 706 tons in 2015 (TUIK, 2015). Unfortunately, biological data pertaining to M. merluccius within this region is extremely limited. However, published studies on age and growth in the northeastern Mediterranean Sea are not currently available. Only information on its distribution and length- 
weight relationships (BAŞUSTA \& ERDEM, 2000; SANGÜN et al., 2007; GIRGIN \& BAŞUSTA, 2016) is available.

The aim of the current study is to give information on growth characteristics and condition factor of European hake from northeastern Mediterranean Sea.

\section{MATERIAL AND METHODS}

European hake specimens were captured by commercial trawler (FV-Nihat Baba) from northeastern Mediterranean (36 $07^{\circ} 148$ N-035 $17^{\prime} 978$ E, 36¹3'720 N-035²2'998 E) (Fig. 1). Fish sampling took place May 2015 and June 2016 at depths ranging from $200 \mathrm{~m}$ to $380 \mathrm{~m}$. A total of $661 \mathrm{M}$. merluccius were sampled during the study period. Fish specimens were transferred to ecophysiology laboratory, Faculty of Fisheries in Firat University. Total length (TL) was measured to the nearest $0.1 \mathrm{~cm}$ and total weight (W) was weighted to the nearest $0.01 \mathrm{~g}$. Sex of the fish specimens was determined by macroscopically examining of gonads.

Whole sagittal otoliths were used for age determination (Fig. 2). However, some otoliths, which were hard to read because of calcium deposition on their surfaces, were prepared for age determinations by sectioning, sanding and polishing (SOYKAN et al., 2015). For this, the otoliths were embedded in epoxy resin with hardener, cut by Ray Tech gem saw and polished with sandpaper (types 400, 800 and 1200) (METIN \& KINACIGIL, 2001) and age determination was applied on these sectioned otoliths. Opaque and transparent rings were counted; 1 opaque zone and 1 transparent zone together were considered 1 annual ring (TURKMEN et al., 2005). The otolith sections were photographed using Leica S8APO brand microscope with Leica Application Suit (Ver. 4.8.0) software. The otoliths parameters such as length and width were measured using Digimizer image analysis software (Ver. 4.8.0) program.

The index of the average percentage error (IAPE) was used to assess the precision of the age determinations between two independent age readers. The equation of IAPE is defined as

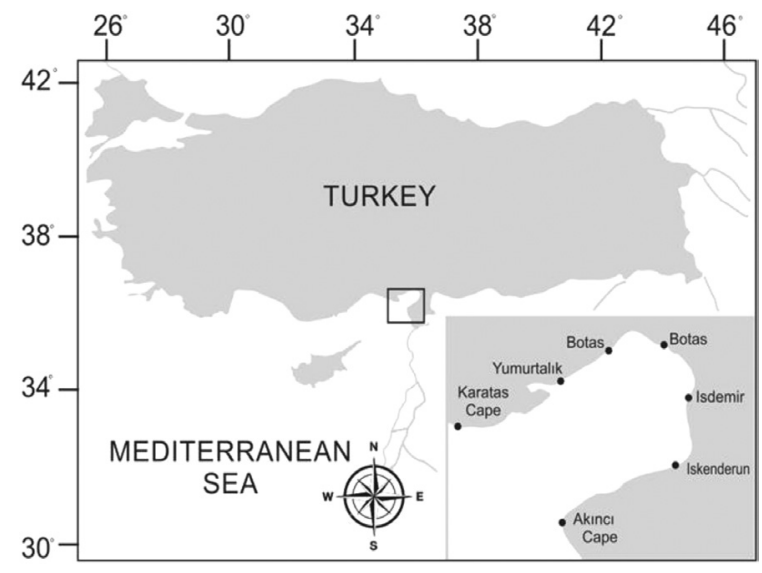

Fig. 1. Merluccius merluccius sampling area in the northeastern Mediterranean Sea

follows: IAPE $=1 / \mathrm{N} \Sigma(1 / \mathrm{R}) \Sigma(x i j-x \mathrm{xj} / \mathrm{xj})$; where $\mathrm{N}$ is the number of fishes aged, $R$ is the number of times each fish was aged, $x i j$ is the ith age determination of the $j t h$ fish, and $x j$ is the mean age calculated for the $j$ th fish (BEAMISH \& FOURNIER, 1981).

The von Bertalanffy growth curve function (VBGF) was fitted to the data with the following model $\mathrm{TL}_{\mathrm{t}}=\mathrm{TL}_{\infty}\left[1-\mathrm{e}^{-\mathrm{k}(\mathrm{t}-\mathrm{t})}\right]$ (Von Bertalanffy, 1938). TLt is the expected total length at age $t$ years. $T L_{\infty}$ is the asymptotic average maximum total length, $k$ is the growth coefficient, and $t_{0}$ is the theoretical age at zero length.

In order to compare $\mathrm{L} \infty$ and $\mathrm{k}$ with those estimated by other authors for the same species, the growth performance index $(\Phi)$ was used, $(\Phi$ $=\operatorname{Ln}(\mathrm{k})+2 \times \operatorname{Ln}(\mathrm{TL} \infty))$ where $k$ and $T L \infty$ are the von Bertalanffy growth parameters (PAULY \& MUNRO, 1984).

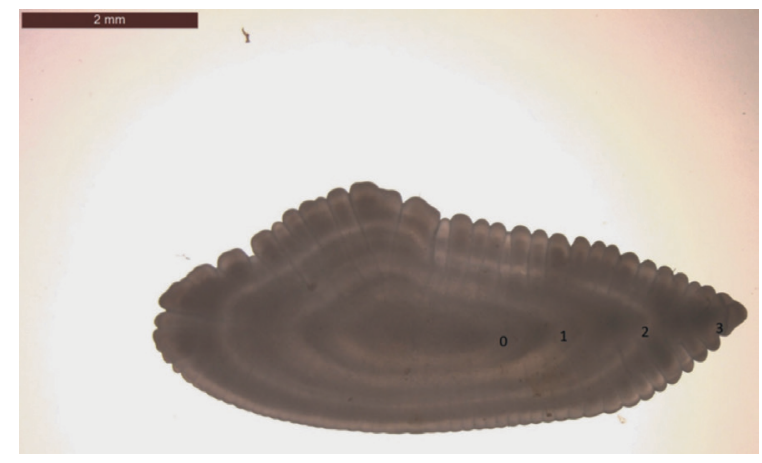

Fig. 2. Sagittal otolith from M. merluccius $(30.1 \mathrm{~cm} \mathrm{TL})$ and estimated to be 3 age 
The absolute length growth (ALG) and the relative length growth (RLG) of fish were computed to RICKER (1975): $\mathrm{ALG}=\mathrm{L}_{\mathrm{n}}-\mathrm{L}_{\mathrm{n}-1} ; \mathrm{RLG}=$ $\left(\mathrm{L}_{\mathrm{n}}-\mathrm{L}_{\mathrm{n}-1} / \mathrm{L}_{\mathrm{n}-1}\right) * 100$, where $\mathrm{L}_{\mathrm{n}}$ is total length at the start of the time interval, and $\mathrm{L}_{\mathrm{n}-1}$ is total length at the end of the time interval.

The values of condition factor were obtained with the formula $K=\left(W / T L^{b}\right) x 100$, where $W$ is total weight; $T L$ is total length and $b$ is the coefficient of allometric of relationship (LE CREN, 1951).

Student's t-test was used in order to test differences in total lengths between the sexes.

\section{RESULTS}

Total 661 individuals of M. merluccius (308 female, 353 male) were collected during the study. The female to male ratio was $1 / 1.15$. Females ranged between 9.8 to $51.3 \mathrm{~cm}$ in total length and 4.96-1430.00 $\mathrm{g}$ in weight and males ranged between 8.1 to $51.6 \mathrm{~cm}$ in total length and $2.60-1726.00 \mathrm{~g}$ in weight. The longest female and male measured at 51.3 and $51.6 \mathrm{~cm}$ in TL, respectively, and their ages ranged from 1 to 7 years. There were no significant differences in total lengths between males and females (t-test, $\mathrm{P}<0.05$ ).

The total length-frequency distribution according to sexes combined is given in Fig. 3. The results showed that most of the individuals were in age group 1 (Table 1).

The index of the average percent error (IAPE) was found by two independent readers that were

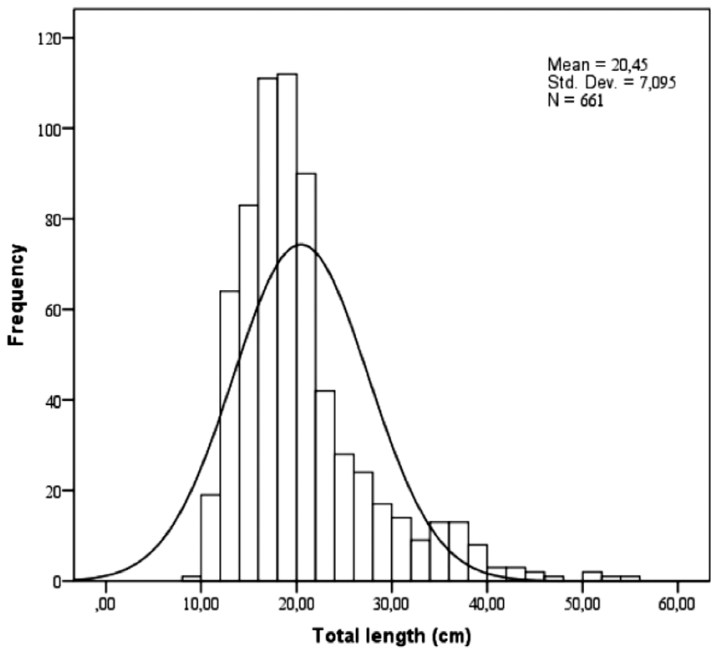

Fig. 3. Total length frequency of $M$. merluccius from northeastern Mediterranean

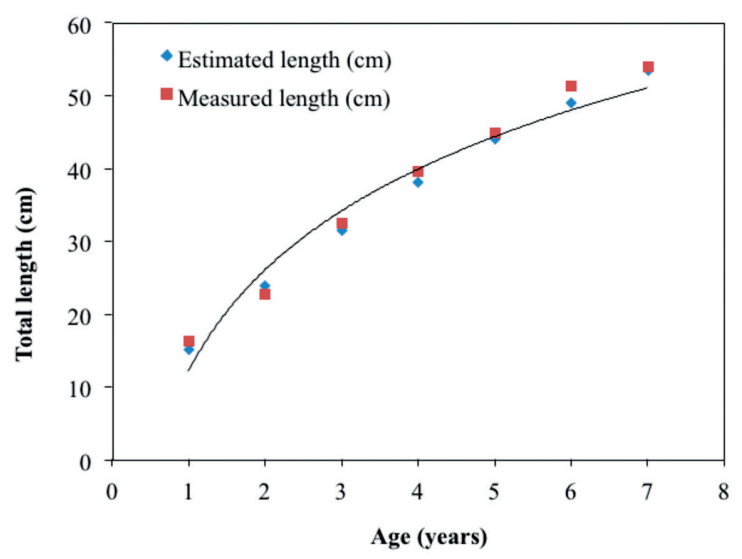

Fig. 4. Age-total length relationship of M. merluccius from northeastern Mediterranean

Table 1. Average total length and weight at age for M. merluccius, sexes combined.

\begin{tabular}{cccccc}
\hline $\begin{array}{c}\text { Age } \\
\text { groups }\end{array}$ & $\mathbf{N}$ & $\begin{array}{c}\text { Average total } \\
\text { length }(\mathbf{c m})\end{array}$ & Size range $\mathbf{( c m )}$ & $\begin{array}{c}\text { Average total } \\
\text { weight }(\mathbf{g})\end{array}$ & Weight range (g) \\
\hline 1 & 407 & 16.37 & $10.20-19.80$ & 30.49 & $5.26-79.88$ \\
2 & 171 & 22.88 & $19.20-28.80$ & 88.04 & $35.33-230.00$ \\
3 & 60 & 32.64 & $28.00-37.80$ & 272.36 & $108.92-462.44$ \\
4 & 15 & 39.70 & $36.30-44.80$ & 465.47 & $205.75-796.63$ \\
5 & 4 & 44.90 & $43.50-47.00$ & 704.75 & $617.00-818.00$ \\
6 & 2 & 51.45 & $51.30-51.60$ & 1202.00 & $1030.00-1374.00$ \\
7 & 2 & 54.00 & $53.00-55.00$ & 1578.00 & $1430.00-1726.00$ \\
\hline
\end{tabular}


Table 2. von Bertalanffy growth parameters for M. merluccius

\begin{tabular}{|c|c|c|c|c|c|c|c|}
\hline Region & Sex & $\mathbf{L}_{\infty}$ & $\mathbf{k}$ & $\mathbf{t}_{\mathbf{0}}$ & $\mathbf{n}$ & $\Phi$ & References \\
\hline $\begin{array}{l}\text { Izmir Bay } \\
\text { (Central } \\
\text { Aegean Sea, } \\
\text { Turkey) }\end{array}$ & All & 54.53 & 0.315 & -0.223 & 2108 & 2.97 & Soykan et al., 2015 \\
\hline $\begin{array}{l}\text { Edremit Bay } \\
\text { (North Aegean } \\
\text { Sea) }\end{array}$ & $\begin{array}{l}\text { Female } \\
\text { Male } \\
\text { All }\end{array}$ & $\begin{array}{l}53.50 \\
47.40 \\
53.90 \\
\end{array}$ & $\begin{array}{l}0.385 \\
0.349 \\
0.377 \\
\end{array}$ & $\begin{array}{l}-0.08 \\
-0.11 \\
-0.05\end{array}$ & $\begin{array}{l}- \\
- \\
2375\end{array}$ & $\begin{array}{c}3.04 \\
2.90 \\
3.04 \\
\end{array}$ & Akalın, 2004 \\
\hline Aegean Sea & All & 81.70 & 0.08 & -1.16 & 336 & 2.75 & Uçkun et al., 2000 \\
\hline $\begin{array}{l}\text { Evoikos } \\
\text { (Greece) } \\
\text { North Aegean } \\
\text { Middle Aegean } \\
\text { Thermaikos } \\
\text { Bay }\end{array}$ & $\begin{array}{l}\text { All } \\
\text { All } \\
\text { All } \\
\text { Female } \\
\text { Male }\end{array}$ & $\begin{array}{l}59.80 \\
65.20 \\
104.0 \\
103.0 \\
117.0\end{array}$ & $\begin{array}{l}0.15 \\
0.10 \\
0.08 \\
0.07 \\
0.06\end{array}$ & $\begin{array}{l}-1.60 \\
-0.17 \\
-1.87 \\
-1.53 \\
-1.57\end{array}$ & $\begin{array}{l}- \\
- \\
- \\
- \\
-\end{array}$ & $\begin{array}{l}2.71 \\
2.64 \\
2.91 \\
2.93 \\
2.89\end{array}$ & $\begin{array}{l}\text { Stergiou et al., } \\
1997\end{array}$ \\
\hline $\begin{array}{l}\text { Northern } \\
\text { Tyrrhenian Sea }\end{array}$ & $\begin{array}{l}\text { Female } \\
\text { Male }\end{array}$ & $\begin{array}{l}92.20 \\
53.30\end{array}$ & $\begin{array}{l}0.131 \\
0.224\end{array}$ & $\begin{array}{l}-0.615 \\
-0.974\end{array}$ & $\begin{array}{l}958 \\
753\end{array}$ & $\begin{array}{l}3.04 \\
2.80\end{array}$ & Ligas et al., 2011 \\
\hline $\begin{array}{l}\text { Gulf of } \\
\text { Alicante }\end{array}$ & $\begin{array}{l}\text { Female } \\
\text { Male } \\
\text { All } \\
\end{array}$ & $\begin{array}{l}108.0 \\
93.00 \\
108.0 \\
\end{array}$ & $\begin{array}{l}0.21 \\
0.20 \\
0.21 \\
\end{array}$ & $\begin{array}{l}0.115 \\
-0.091 \\
0.12 \\
\end{array}$ & $\begin{array}{l}- \\
- \\
41461 \\
\end{array}$ & $\begin{array}{c}3.42 \\
3.24 \\
3.39 \\
\end{array}$ & $\begin{array}{l}\text { Garcia-Rodriquez } \\
\& \text { Esteban, } 2002\end{array}$ \\
\hline $\begin{array}{l}\text { Atlantic Coast } \\
\text { of Iberia } \\
\text { (Spain) }\end{array}$ & $\begin{array}{l}\text { Female } \\
\text { Male }\end{array}$ & $\begin{array}{l}89.00 \\
70.00\end{array}$ & $\begin{array}{l}0.13 \\
0.18\end{array}$ & $\begin{array}{l}-1.15 \\
-0.97\end{array}$ & $\begin{array}{l}469 \\
315\end{array}$ & $\begin{array}{l}3.01 \\
2.95\end{array}$ & $\begin{array}{l}\text { Pineiro \& Sainza, } \\
2003\end{array}$ \\
\hline $\begin{array}{l}\text { Bay of Lion } \\
\text { (France) }\end{array}$ & $\begin{array}{l}\text { Female } \\
\text { Male }\end{array}$ & $\begin{array}{l}80.20 \\
55.80 \\
\end{array}$ & $\begin{array}{l}0.11 \\
0.18 \\
\end{array}$ & $\begin{array}{l}-0.52 \\
-0.42 \\
\end{array}$ & $\begin{array}{l}958 \\
753 \\
\end{array}$ & $\begin{array}{l}2.84 \\
2.75 \\
\end{array}$ & Compillo, 1992 \\
\hline Bay of Biscay & All & 89.90 & 0.36 & - & - & 3.46 & $\begin{array}{l}\text { de Pontual et al., } \\
2006\end{array}$ \\
\hline $\begin{array}{l}\text { Marmara Sea } \\
\text { (Turkey) }\end{array}$ & $\begin{array}{l}\text { Female } \\
\text { Male } \\
\text { All } \\
\end{array}$ & $\begin{array}{l}106.36 \\
102.43 \\
103.9 \\
\end{array}$ & $\begin{array}{l}0.08 \\
0.09 \\
0.08 \\
\end{array}$ & $\begin{array}{l}-1.09 \\
-0.82 \\
-0.92 \\
\end{array}$ & $\begin{array}{l}341 \\
192 \\
767 \\
\end{array}$ & $\begin{array}{l}2.96 \\
2.83\end{array}$ & $\begin{array}{l}\text { Kahraman et al., } \\
2017\end{array}$ \\
\hline $\begin{array}{l}\text { Northern } \\
\text { Aegean } \\
\text { (Turkey) }\end{array}$ & $\begin{array}{l}\text { Female } \\
\text { Male } \\
\text { All } \\
\end{array}$ & $\begin{array}{l}102.3 \\
88.54 \\
102.6 \\
\end{array}$ & $\begin{array}{l}0.09 \\
0.10 \\
0.9 \\
\end{array}$ & $\begin{array}{l}-1.31 \\
-0.99 \\
-0.80 \\
\end{array}$ & $\begin{array}{l}708 \\
1126 \\
1834 \\
\end{array}$ & $\begin{array}{l}2.97 \\
2.93 \\
3.01 \\
\end{array}$ & Uzer et al., 2019 \\
\hline $\begin{array}{l}\text { Marmara Sea } \\
\text { (Turkey) }\end{array}$ & $\begin{array}{l}\text { Female } \\
\text { Male } \\
\text { All } \\
\end{array}$ & $\begin{array}{l}53.0 \\
44.2 \\
57.5 \\
\end{array}$ & $\begin{array}{l}0.30 \\
0.38 \\
0.27 \\
\end{array}$ & $\begin{array}{l}-0.47 \\
-0.39 \\
-0.57 \\
\end{array}$ & $\begin{array}{l}117 \\
75 \\
193 \\
\end{array}$ & - & Gül et al., 2019 \\
\hline $\begin{array}{l}\text { North-eastern } \\
\text { Mediterrenean } \\
\text { (Turkey) }\end{array}$ & $\begin{array}{l}\text { Female } \\
\text { Male } \\
\text { All }\end{array}$ & $\begin{array}{l}93.98 \\
77.65 \\
84.44\end{array}$ & $\begin{array}{l}0.114 \\
0.153 \\
0.135\end{array}$ & $\begin{array}{l}-0.597 \\
-0.343 \\
-0.469\end{array}$ & $\begin{array}{l}316 \\
356 \\
672\end{array}$ & $\begin{array}{l}3.00 \\
2.96 \\
2.98\end{array}$ & This study \\
\hline
\end{tabular}


Table 3. Age-total length structure of M. merluccius

\begin{tabular}{|c|c|c|c|c|c|c|c|c|c|}
\hline \multirow[t]{2}{*}{ Lengths (cm) } & & \multicolumn{8}{|c|}{ Age Classes } \\
\hline & & $\mathbf{I}$ & II & III & IV & V & VI & VII & Total \\
\hline \multirow{2}{*}{$\leq 10$} & $\mathrm{~F}$ & 1 & & & & & & & \\
\hline & $\mathrm{M}$ & & & & & & & & \\
\hline \multirow{2}{*}{$10.1-14$} & $\mathrm{~F}$ & 27 & & & & & & & \\
\hline & $\mathrm{M}$ & 59 & & & & & & & \\
\hline \multirow{2}{*}{$14.1-18$} & $\mathrm{~F}$ & 94 & & & & & & & \\
\hline & $\mathrm{M}$ & 109 & & & & & & & \\
\hline \multirow{2}{*}{$18.1-22$} & $\mathrm{~F}$ & 59 & 41 & & & & & & \\
\hline & $\mathrm{M}$ & 55 & 42 & & & & & & \\
\hline \multirow{2}{*}{ 22.1-26 } & $\mathrm{F}$ & 3 & 25 & & & & & & \\
\hline & $\mathrm{M}$ & & 37 & & & & & & \\
\hline \multirow{2}{*}{ 26.1-30 } & $\mathrm{F}$ & & 7 & 8 & & & & & \\
\hline & $\mathrm{M}$ & & 18 & 6 & & & & & \\
\hline \multirow{2}{*}{ 30.1-34 } & $\mathrm{F}$ & & 1 & 12 & & & & & \\
\hline & $\mathrm{M}$ & & & 10 & & & & & \\
\hline \multirow{2}{*}{ 34.1-38 } & $\mathrm{F}$ & & & 16 & 3 & & & & \\
\hline & $\mathrm{M}$ & & & 8 & & & & & \\
\hline \multirow{2}{*}{$38.1-42$} & $\mathrm{~F}$ & & & & 8 & & & & \\
\hline & $\mathrm{M}$ & & & & 2 & & & & \\
\hline \multirow{2}{*}{ 42.1-46 } & $\mathrm{F}$ & & & & 2 & 1 & & & \\
\hline & $\mathrm{M}$ & & & & & 2 & & & \\
\hline \multirow{2}{*}{ 46.1-50 } & $\mathrm{F}$ & & & & & 1 & & & \\
\hline & $\mathrm{M}$ & & & & & & & & \\
\hline \multirow{2}{*}{$>\mathbf{5 0}$} & $\mathrm{F}$ & & & & & & 1 & 1 & \\
\hline & $\mathrm{M}$ & & & & & & 1 & 1 & \\
\hline \multirow{4}{*}{$\begin{array}{l}\text { Combined } \\
\text { sexes }\end{array}$} & $\mathrm{N}$ & 407 & 171 & 60 & 15 & 4 & 2 & 2 & 661 \\
\hline & N\% & 61.57 & 25.87 & 9.08 & 2.27 & 0.61 & 0.30 & 0.30 & 100.00 \\
\hline & $\begin{array}{l}\text { Mean TL } \\
(\mathrm{cm})\end{array}$ & 16.37 & 22.88 & 32.64 & 39.70 & 44.90 & 51.45 & 54.00 & \\
\hline & SD & 2.58 & 2.49 & 3.02 & 2.35 & 1.68 & 0.21 & 1.41 & \\
\hline \multirow{4}{*}{ Female } & $\mathrm{N}$ & 181 & 74 & 36 & 13 & 2 & 1 & 1 & 308 \\
\hline & N\% & 27.38 & 11.20 & 5.45 & 1.97 & 0.30 & 0.15 & 0.15 & 46.60 \\
\hline & $\begin{array}{l}\text { Mean TL } \\
(\mathrm{cm})\end{array}$ & 16.78 & 22.67 & 32.85 & 39.82 & 46.25 & 51.30 & 53.00 & \\
\hline & SD & 2.40 & 2.43 & 2.98 & 2.52 & 1.06 & 0.00 & 0.00 & \\
\hline \multirow{4}{*}{ Male } & $\mathrm{N}$ & 226 & 97 & 24 & 2 & 2 & 1 & 1 & 353 \\
\hline & N\% & 34.19 & 14.67 & 3.63 & 0.30 & 0.30 & 0.15 & 0.15 & 53.40 \\
\hline & $\begin{array}{l}\text { Mean TL } \\
(\mathrm{cm})\end{array}$ & 16.04 & 23.05 & 32.33 & 38.95 & 43.55 & 51.60 & 55.00 & \\
\hline & SD & 2.68 & 2.54 & 3.10 & 0.07 & 0.07 & 0.00 & 0.00 & \\
\hline
\end{tabular}


Table 4. Average condition factors, absolute growth and relative growth values of $\mathrm{M}$. merluccius

\begin{tabular}{cccc}
\hline Age Groups & Condition Factors & Absolute Growth & Relative Growth (\%) \\
\hline 1 & 0.63 & 6.51 & 39.80 \\
2 & 0.70 & 9.76 & 42.64 \\
3 & 0.76 & 7.06 & 21.63 \\
4 & 0.73 & 5.20 & 13.10 \\
5 & 0.78 & 6.55 & 14.59 \\
6 & 0.88 & 2.55 & 4.96 \\
7 & 1.01 & & \\
Average $\pm \mathrm{SD}$ & $0.784 \pm 0.047$ & & \\
\hline
\end{tabular}

oblivious of each other. IAPE was found as 5.22 $\%$ for $M$. merluccius.

In this study, the von Bertanffly growth equation (VBGE) was estimated to be $\mathrm{TL}_{t}=84.44[1-$ $\mathrm{e}^{-0.135\left({ }^{(+0.469)}\right]}$ taking all specimens (Fig. 4), $\mathrm{TL}_{t}=93.98\left[1-\mathrm{e}^{-0.114}\left({ }^{(t+0.597)}\right]\right.$ for females and $\mathrm{TL}_{t}=77.65\left[1-\mathrm{e}^{-0.153(t+0.343)}\right]$ for males by considering the total length of fish based on the population of M. merluccius found in the northeastern Mediterranean (Tables 2 and 3). According to the VBGE, calculated lengths were found similar to measured lengths.

The maximum absolute growth and relative growth rate in $M$. merluccius were calculated as $9.76 \mathrm{~cm}$ and $42.64 \%$ between 2 and 3 age groups, respectively. After age 3, both absolute and relative growth started to decrease by increasing of age. The least growth was appeared between 6 and 7 age groups with 2.55 $\mathrm{cm}$ absolute growth and $4.96 \%$ relative growth rate (Table 4).

The growth performance value $(\Phi)$ of the European hake population was calculated as 2.98 for combined sexes, 3.0 for females and 2.96 for males.

The condition factor of $M$. merluccius was calculated for all age groups and is presented (Table 4). Mean value and standard deviation (SD) of the condition factor of the population was $0.784 \pm 0.047$ and the highest value was found as 1.01 in age group 7.

\section{DISCUSSION}

There is no information on the growth studies for European hake in the northeastern Mediterranean. The lack of biological information hinders implementation of fishery management strategies for European hake in the northeastern Mediterranean Sea. Our data showed that males are more numerous than females (1.15/1). GÜL et al. (2019) reported the male to female ratio as 1/1.15 from the Sea of Marmara. This may be due to differences in the sampling time periods that were performed in different years. GRINOLS \& TILLMAN (1970) reported that in spawning Merluccius productus schools, the sex ratio favors males and may be twice that of nonspawning schools.

Sagittal otoliths were read at least twice to confirm the age estimations by independent age readers. Index of APE value (5.22\%) was within acceptable limits. In this study, the age range of the fish samples was 1-7 years old. The highest age for this species was firstly recorded in Turkish seas in this study.

The maximum total length $(51.6 \mathrm{~cm})$ in our study were more than those of reported (TL, 
$43.5 \mathrm{~cm}$ and $45.5 \mathrm{~cm}$ ) from the Central Aegean Sea by UÇKUN et al. (2000) and SOYKAN et al. (2015) respectively.

There have been some scientific researches on the growth parameters of the European hake (Table 2), and these parameters were found as $L_{\infty}=84.44 \mathrm{~cm}, k=0.135$ year $^{-1}, t_{0}=-0.469$ year for combined sexes in the present study. The longest asymptotic length $\left(L_{\infty}\right)$ was estimated for Turkish Seas in this study (Table 2). Lo value for females $(93.98 \mathrm{~cm})$ was relatively greater than that for males $(77.65 \mathrm{~cm})$, indicating that the females grew relatively faster than the males. These values relatively agree with many estimated parameters from the western Mediterranean and other areas. According to BECKMAN \& WILSON (1995), these differences could be attributed to the different fishing area and dependent on both abiotic and biotic environmental factors. Males were found longer and heavier than females and the Brody growth coefficient $(k)$ was higher in males than that in females.

The growth performance values $(\Phi)$ of the other studies from different areas ranged between 2.64 and 3.46 (Table 2), and show similarities especially with the findings of other studies. There was no statistically significance between our growth performance value and the values in other studies $(t$-test; $\mathrm{P}>0.05)$.
Studies on the growth and condition factor of M. merluccius is very scarce in the eastern Mediterranean and so more studies should be done to establish their stock availability. Thus, information on growth parameters and condition factor of European hake in the northeastern Mediterranean was firstly found out during 2015-2016 fishing season in this study. According to relative growth values, growth rate decreases after 2 years old. Size range in 2 years old is between 19.20 and $28.8 \mathrm{~cm}$ (average 22.88). It is evaluated that the minimum length limit for fishing should be $23 \mathrm{~cm}$. UZER et al. (2019) reported that the minimum landing size in the Turkish waters should be increased from 20 $\mathrm{cm}$ to $25 \mathrm{~cm}$ to ensure at least single breeding of Merluccius merluccius. These values are very close to our findings. These results can be used as biological parameters in further stock evaluations in this region.

\section{ACKNOWLEDGEMENTS}

The authors thank F/V Nihat Baba 3 crew for their assistance for obtaining the fish sample; warmly thank Prof. Dr. Metin Çalta, for his valuable help and advice. This study is a part of Ph.D. Thesis prepared by Hulya Girgin in Firat University, Turkey.

\section{REFERENCES}

AKALIN, S. 2004. Investigations of the age and growth characteristics of European hake (Merluccius merluccius L., 1758) in Edremit Bay. PhD thesis (in Turkish). Ege University, Turkey, 133 pp.

BAŞUSTA, N. \& U. ERDEM. 2000. A Study on the pelagic and demersal fishes of Iskenderun Bay (in Turkish). Turkish Journal of Zoology. 24 (supp.): 1-19.

BEAMISH, R. J. \& D. A. FOURNIER. 1981. A method for comparing the precision of a set of age determinations. Canadian Journal of Fisheries Aquatic Science, 38: 982-983.

BECKMAN, D. W. \& C. A. WILSON. 1995. Seasonal timing of opaque zone formation in fish oto- liths. In Secor D.H., Dean J.M. and Campana S.E. (Editors). Recent developments in fish otolith research. Columbia, SC: University of South Carolina Press, pp. 27-44.

COMPILlO, A. 1992. Les Pecheries Francaises de Mediteranee: Synthese des Connaissances. Institut Francais de Recherche pour l'Exploitation de la Mer (IFREMER), IFREMER Report, 206 pp.

DE PONTUAL H., A.L. GROISON, C. PIÑEIRO \& M. BERTIGNAC. 2006. Evidence of underestimation of European hake growth in the Bay of Biscay, and its relationship with bias in the agreed method of age estimation. ICES Journal of Marine Science, 63: 1674-1681. 
FAO, 2017. FAO Fisheries and Aquaculture Department. http://www.fao.org/fishery/species /2238/en (accessed 28 February 2017).

GARCÍA-RODRÍGUEZ, M. \& A. ESTEBAN. 2002. How fast does hake grow? A study on the Mediterranean hake (Merluccius merluccius L.) comparing whole otoliths readings and length frequency distribution data. Scientia Marina, 66: 145-156.

GIRGIN, H. \& N. BAŞUSTA. 2016. Length-weight relationship of European hake (Merluccius merluccius) caught from Northeastern Mediterranean. International Science Symposium (September 01-04, 2016), Istanbul-Turkey. Proceeding Book.5A6PB; pp:319-324.

GOLANI, D., B. OZTÜRK \& N. BAŞUSTA. 2006. Fishes of the Eastern Mediterranean. Turkish Marine Research Foundation, Istanbul, Turkey. Pub. Number: 24, 259 p.

GRINOLS, R. G. \& M. F. TILLMAN. 1970. Importance of the worldwide hake, Merluccius, resource. Cire. Fish Wildl. Serv. Wash. 332: 1-21.

GÜL, G., E. MURAT-DALKARA, A. YÜKSEK \& N. DEMIREL. 2019. Age and Growth of European Hake, Merluccius merluccius in The Sea of Marmara. COMU Journal of Marine Science and Fisheries, 2(2): 147-154.

KAHRAMAN, A.E., T. YILDIZ, U. UZER \& F.S. KARAKULAK. 2017. Age composition, growth and mortality of European hake Merluccius merluccius (Linnaeus, 1758) (Actinopterygii: Merlucciidae) from the Sea of Marmara, Turkey, Acta Zoologica Bulgarica, 69 (3): 377-384.

LE CREN, E. D. 1951. The length-relationship and seasonal cycle in gonad weight and condition in the Perch (Perca fluviatilis). Journal of Animal Ecology, 20: 210-218.

LIGAS, A., C. PIERATTINI, C. VIVA, D. BERTOLINI \& P. BELCARI. 2011. Age estimation and growth of European hake, Merluccius merluccius (Linnaeus, 1758), in the Northern Tyrrhenian Sea. Atti Soc. tosc. Sci. nat., Mem., Serie B, 118, p.9-14.

METIN, G. \& H.T. KINACIGIL. 2001. The sectioning technique in age determination by otolith. EU Journal of Fisheries and Aquatic Sciences 18, 271-277.
PAULY, D. \& J. L. MUNRO. 1984. Once more on the comparison of growth in fish and invertebrates. Fishbyte 2 (1): 21 pp.

PINEIRO, C. \& M. SAINZA, 2003. Age estimation, growth and maturity of the European hake (Merluccius merluccius (Linnaeus, 1758)) from Iberian Atlantic waters. ICES Journal of Marine Science 60: 1086-1102.

RICKER, W. E. 1975. Computation and Interpretation of Biological Statistics of Fish Populations. Bulletin of the Fisheries Research Board of Canada, Ottawa, No 119: 1-29 pp.

SANGÜN, L., E. AKAMCA, M. AKAR. 2007. Weightlength relationships for 39 fish species from the North-Eastern Mediterranean coast of Turkey. Turkish Journal of Fisheries and Aquatic Sciences 7: 37-40.

SOYKAN, O., A.T. ILKYAZ, G. METIN \& H.T. KINACIGIL. 2015. Age, growth and reproduction of European hake (Merluccius merluccius (Linn., 1758)) in the Central Aegean Sea, Turkey. Journal of the Marine Biological Association of the United Kingdom, 95(4): $829-837$.

STERGIOU, K.I., E.D. CHRISTOU, D. GEORGOPOULOUS, A. ZENETOS \& C. SOUVERMEZOGLOU. 1997. Oceanography and marine biology: an annual review. In Ansell A.D., Gibson R.N. and Barnes M. (Editors) The Hellenic seas: physics, chemistry, biology and fisheries. London: UCL Press, pp. 415-538.

TUIK, (Turkish Statistical Institute) 2015. Fishery statistics 2015. Ankara: TUIK.

TURKMEN, M., N. BAŞUSTA \& S. A. DEMIRHAN. 2005. Ageing in fish. In Karatas M. (Ed.) Research techniques in fish biology. Ankara, Turkey: Nobel Publications, pp.21-148. (Chapter in Turkish).

UÇKUN, D., TOGULGA M. \& E. TASKAVAK. 2000. A preliminary study on the growth of the common hake (Merluccius merluccius L., 1758) in Izmir Bay, Aegean Sea. Acta Adriat.,41 $25-34$.

UZER, U., B. ÖZTÜRK \& T. YILDIZ. 2019. Age composition, growth, and mortality of European hake Merluccius merluccius (Actinopterygii: Gadiformes: Merlucciidae) from The Northern Aegean Sea, Turkey. Acta Ichthyologica 
Et Piscatoria, 49 (2): 109-117. DOI: 10.3750/ AIEP/02465
VON BERTALANFFY, L. 1938. A quantitative theory of organic growth, Human Biology 10:181213.

Received: 20 January 2020

Accepted: 16 March 2020

\title{
Značajke rasta oslića, Merluccius merluccius (Linnaeus, 1758.), u sjeveroistočnom dijelu Sredozemnog mora
}

\author{
Hulya GIRGIN i Nuri BAŞUSTA \\ *Kontakt e-pošta: nbasusta@firat.edu.tr
}

\section{SAŽETAK}

U ovom radu istraženi su starost i neke značajke rasta oslića, Merluccius merluccius, u sjeveroistočnom dijelu Sredozemmnog mora, tijekom ribolovne sezone 2015-2016.

Koćom je ukupno ulovljeno 661 jedinka oslića čija je ukupna duljina kolebala u rasponu od 9,8 do $51,6 \mathrm{~cm}$. Omjer između ženki i mužjaka je iznosio 1:1,15. Procjena starosti je provedena pomoću očitavanja sagitalnih otolita. Starost jedinki se kretala u rasponu od 1 do 7 godina.

Parametri rasta prema von Bertalanffy-jevoj jednadžbi prilagođeni su prosječno izmjerenim ukupnim duljinama po starosti za svaki spol odvojeno i procijenjeni kao $\mathrm{L} \infty=93,98 \mathrm{~cm}, \mathrm{k}=0,114$ godina $^{-1}, \mathrm{t}_{0}=-0,597$ godina za ženke, te kao $\mathrm{L} \infty=77,65 \mathrm{~cm}, \mathrm{k}=0,153$ godina $^{-1}, \mathrm{t}_{0}=-0,343$ godina za mužjake i $\mathrm{L} \infty=84,44 \mathrm{~cm}, \mathrm{k}=0,135$ godina $^{-1}, \mathrm{t}_{0}=-0,469$ godina za oba spola.

Vrijednost rasta $(\Phi)$ u populaciji oslića izračunata je kao 2,98 za oba spola. Srednja vrijednost kondicijskog čimbenika populacije iznosila je 0,654 $\pm 0,021$; najveći utvrđeni kondicijski čimbenik iznosio je 1.01 kod riba u dobi od 7 godina.

Ključne riječi: oslić, Merluccius merluccius, starost, rast, sjeveroistočno Sredozemlje, kondicijski čimbenik 
